\title{
Diagnosis and treatment of head and neck sarcomas: personal experiences
}

\author{
Melissa Laus*, Domenico Crescenzi, Antonio Moretti, Adelchi Croce \\ ENT Department, University “G. D’Annunzio” of Chieti-Pescara, Hospital “SS. Annunziata”, Via dei Vestini, 66100 Chieti, Italy
}

Email adress:

melissa.laus@hotmail.it(M. Laus)

\section{To cite this article:}

Melissa Laus, Domenico Crescenzi, Antonio Moretti, Adelchi Croce, Diagnosis and Treatment of Head and Neck Sarcomas: Personal Experiences. Journal of Cancer Treatment and Research. Vol. 1, No. 1, 2013, pp. 1-7. doi: 10.11648/j.jctr.20130101.11

\begin{abstract}
Sarcomas are a rare group of tumors. They do not commonly manifest as malignancies in the head and neck region. The rare nature of these tumors has resulted in a limited number of publications. This is a descriptive study. We included patients with primary sarcomas of the head and neck, observed between 1991 and 2011 in the department of Otorhinolaryngology (University of Chieti, Italy). We studied the following variables: age, gender, race, origin, primary anatomical location of the neoplasm, pathology, diagnosis and type of cancer treatment employed. During the study period, we found 9 patients with head and neck sarcomas. Of this sample, 6 were males, and 3 were females. The man/woman ratio was $2: 1$. As far as age is concerned, the most affected age range was between 60 and 80 years. The mean age of the patients was 62. As far as pathology is concerned, we found 7 histopathological variations of sarcomas, and the most common type was the leiomyosarcoma. The most widely used treatment modality was surgical treatment. The data in this study show that head and neck sarcomas are rare tumors with high histological variability, which may involve different anatomical sites. Since these are rare and not well-known lesions, further epidemiological studies must be carried out, in order to give us more knowledge about the disease.
\end{abstract}

Keywords: Sarcoma, Head and Neck, Multivariate Analysis, Treatment Outcomes

\section{Introduction}

Sarcomas are a heterogeneous group of malignant neoplasms having as a common denominator their origin from mesenchymal cells. About $15 \%$ to $20 \%$ of all sarcomas are diagnosed in head and neck region [1-2]. These neoplasms are designated by their tissue of origin, histologic grade and anatomic subsite of head and neck region in which they are found. Approximately the $80 \%$ are of the soft tissue type while approximately the $20 \%$ are of bony or cartilaginous origin [3]. Muscle, vessel, nerve, fat and fibrous tissue can each give origin to a heterogenous group of malignancies whose histologic characteristics reflect their tissue of origin. Some types have no clear association with any particular tissue, and it remains unclear which soft tissue elements potentiate these lesions [4]. Histologic grade is a reliable predictor of prognosis. Most head and neck soft tissue sarcomas are high grade [5]. These malignancies occur in the nasal cavity, paranasal sinuses, nasopharynx, hypopharnyx, oropharynx, ear, scalp, oral cavity and salivary glands [6]. The most common histological types are: osteosarcoma, rhabdomyosarcoma, pleomorphic sarcoma and angiosarcoma [7-8]. The histopathological examination of the lesions is important for their treatment. In fact, the treatment depended more on grade, stage and operative considerations in relation to the site.

\section{Materials and Methods}

We have collected patient, tumour, treatment, and outcome data on all patients with bone and soft tissue sarcomas for 20 years at the our department of Otorhinolaryngology (University of Chieti, Italy). During the study period, we found 9 patients with head and neck sarcomas. Of this sampleall subjects of white race, 6 were males, and 3 were females. We have identified all patients with soft tissue sarcomas in the head and neck, defined as sites above the level of the clavicle. We have made a number of observations related to patient demographics, tumour variables, treatment modalities, outcome, and follow up for patients with head and neck soft tissue sarcomas. The results were plotted in Table 1. 
Table 1. Patient, age, sex, site of origin, diagnosis, treatment, follow up

\begin{tabular}{|c|c|c|c|c|c|c|}
\hline Case & Age & Sex & Site of Origin & Diagnosis & Treatment & Follow-Up \\
\hline $\begin{array}{c}\text { I } \\
(1991)\end{array}$ & $\begin{array}{c}6 \\
\text { age }\end{array}$ & $\mathrm{W}$ & $\begin{array}{l}\text { Nasophrynx and left } \\
\text { mastoid and temporal } \\
\text { region }\end{array}$ & $\begin{array}{l}\text { Embryonal } \\
\text { rhabdomyosarcoma } \\
\text { parameningeal }\end{array}$ & Chemotherapy & $\begin{array}{l}\text { Tumor recurrence in the '95, '97, '05 and } \\
\text { died in the '06. }\end{array}$ \\
\hline $\begin{array}{c}\text { II } \\
(2001)\end{array}$ & $\begin{array}{c}68 \\
\text { age }\end{array}$ & $\mathrm{W}$ & Thyroid & Leiomyosarcoma & Surgical treatment & Died after 6-7 months. \\
\hline $\begin{array}{c}\text { III } \\
(2002)\end{array}$ & $\begin{array}{l}76 \\
\text { age }\end{array}$ & $\mathrm{M}$ & $\begin{array}{l}\text { Right parapharyngeal } \\
\text { region }\end{array}$ & Kaposi's sarcoma & $\begin{array}{l}\text { Treatment with } \\
\alpha \text {-interferon }\end{array}$ & Died of acute myocardial infarction . \\
\hline $\begin{array}{c}\text { IV } \\
(2004)\end{array}$ & $\begin{array}{c}62 \\
\text { age }\end{array}$ & $\mathrm{M}$ & Left parotid & Epithelioid sarcoma & Surgical treatment & Died after 6-7 months. \\
\hline $\begin{array}{c}V \\
(2005)\end{array}$ & $\begin{array}{c}70 \\
\text { age }\end{array}$ & $\mathrm{M}$ & Larynx & Leiomyosarcoma & $\begin{array}{l}\text { Surgical treatment } \\
\text { (partial } \\
\text { laryngectomy) }\end{array}$ & $\begin{array}{c}\text { Tumor recurrence in the ' } 07 \text { (total } \\
\text { laryngectomy) and no tumor recurrence after } \\
5 \text { years. }\end{array}$ \\
\hline $\begin{array}{c}\text { VI } \\
(2006)\end{array}$ & $\begin{array}{c}71 \\
\text { age }\end{array}$ & $\mathrm{W}$ & Right nasal cavity & Chondrosarcoma & Surgical treatment & $\begin{array}{l}\text { Tumor recurrence in the ' } 06 \text { (surgery) and } \\
\text { no tumor recurrence after } 5 \text { years. }\end{array}$ \\
\hline $\begin{array}{l}\text { VII } \\
(2007)\end{array}$ & $\begin{array}{c}74 \\
\text { age }\end{array}$ & $\mathrm{M}$ & $\begin{array}{l}\text { Left fronto-parietal } \\
\text { region }\end{array}$ & $\begin{array}{l}\text { Malignant peripheral } \\
\text { nerve sheat tumor } \\
\text { (MPNST) }\end{array}$ & Surgical treatment & $\begin{array}{l}\text { Tumor recurrence in the '11 (parotidectomy } \\
\text { and radio-chemotherapy). }\end{array}$ \\
\hline $\begin{array}{l}\text { VIII } \\
(2009)\end{array}$ & $\begin{array}{c}53 \\
\text { age }\end{array}$ & $\mathrm{M}$ & $\begin{array}{l}\text { Parotid and right } \\
\text { headset region }\end{array}$ & Myxofibrosarcoma & Surgical treatment & No tumor recurrence after 2 years. \\
\hline $\begin{array}{c}\text { IX } \\
(2011)\end{array}$ & $\begin{array}{c}77 \\
\text { age }\end{array}$ & $\mathrm{M}$ & $\begin{array}{l}\text { Base of the tongue and } \\
\text { free edge of the } \\
\text { epiglottis }\end{array}$ & Leiomyosarcoma & Surgical treatment & No tumor recurrence after 8 months. \\
\hline
\end{tabular}

Sarcomas of the head and neck are rare mesenchymal malignant neoplasms accounting for less than $10 \%$ of all soft tissue sarcomas and approximately $1 \%$ of all head and neck

neoplasms 85, 9-139. There are several histological subtypes of sarcoma (Table 2) which present with a variety of clinical characteristics [14].

Table 2. Classification of head and neck sarcomas

\section{- MALIGNANT SOFT-TISSUE TUMORS}

(Fibrosarcoma, Pleomorphic sarcoma or so-called malignant fibrous histiocytoma, Leiomyosarcoma, Rhabdomyosarcoma, Angiosarcoma, Liposarcoma, Sinovial sarcoma, Epithelioid sarcoma, Kaposi sarcoma, Malignant peripheral nerve sheath tumor, Dermatofibrosarcoma protuberans, Alveolar soft-parts sarcoma.)

- MALIGNANT TUMORS OF BONE AND CARTILAGE

(Condrosarcoma, Osteosarcoma.)

- HEMATOLYMPHOID TUMORS

(Extramedullary myeloid sarcoma, Histiocytic sarcoma, Follicular dendritic cell sarcoma/tumor.)

- NEUROECTODERMAL TUMORS

(Ewing sarcoma.)

- ODONTOGENIC SARCOMAS

(Ameloblastic fibrosarcom.)

- RADIATION-INDUCED SARCOMAS
Among these different subtypes we think it could be useful to present the clinical characteristics of the tumors we observed:

\subsection{Leiomyosarcoma (3 case)}

It is the least common soft tissue sarcomas to originate in the head and neck region, probably because of the paucity of smooth muscle tissue [15]. The source of smooth muscle tumors in oral cavity may be the arterial tunica media, the ductus lingualis, the circumvallate papillae and pluripotential mesenchymal cells. The jawbones appear to be the site of predilection for oral leiomyosarcomas [16]. Other intraoral locations include the tongue, cheek, gingival, soft palate, upper lip and floor of mouth. Other location is neurovascular bundles of the facial bones [17]. Patients generally presents in fifth or sixth decade of life. In our experience this subtype was the most frequent and it grew also in old patients.

\subsection{Rhabdomyosarcoma (1 case)}

It is an aggressive soft tissue sarcoma of children and adolescents involving the head and neck region [18-21]. It is subdivided into three major groups: embryonal (most common in children and teenagers), alveolar and pleomorphic (most common in adults) [22]. Men and women are nearly equally affected [20-21, 23].

\subsection{Fibrosarcoma (1 case)}

It is considered the second most common soft-tissue sarcomas after rhabdomyosarcoma in the head and neck. It occur in all ages, with a peak in the fifth decade. There is a 3:2 female:male gender predilection [7]. Usually, it appears as a painless firm mass of the scalp, face, or neck [24-26]. 
The fibrosarcoma is characterized by high local recurrence rate and a low incidence of locoregional lymph node and/or distant hematogenous metastases [27]. Myxofibrosarcoma is one of its variety with fibrotic myxoid elements.

\subsection{Epithelioid sarcoma (1 case)}

Epithelioid sarcoma is a histologically distinct malignant soft tissue sarcoma of uncertain histogenesis [6]. It mainly occurs in young adults from 15-40 years of age and has a predilection for the fingers, hands, forearms and lower limbs. It is very rare on the trunk and head and neck regions. The clinical presentation is usually that of a slowly growing, painless swelling, which may be a solitary nodule or, more rarely, consists of multiple nodules and has firm consistency [28].

\subsection{Kaposi's sarcoma (1 case)}

Kaposi's sarcoma is an angioproliferative disorder characterized by proliferation of spindle-shaped cells, neo-angiogenesis, inflammation and edema [29-30]. Four major forms have been identified: Classic, African endemic, Immunosuppression-associated or transplant-associated, and AIDS-associated [31-32]. A new Kaposi's sarcoma-type in HIV-negative men having sex with men has been described in a recent cohort study [33]. Whilst head and neck involvement is frequent in AIDS-associated Kaposi's sarcoma, craniofacial manifestations in the other Kaposi's sarcoma varieties are scarce [30, 34]. Kaposi's sarcoma-lesions occur in ten variants: patch, plaque, nodular, lymphadenopathic, exophytic, infiltrative, telangiectatic, ecchymotic, keloid, and cavernous or lymphangioma-like [35-36]. Have been described in the literature cases of classic Kaposi's sarcoma with oral involvement [37]. The hard palate and gengive are most frequent locations [37]. Additional sites include the tongue, buccal mucosa, lips, submandibular duct area, parotid gland, and intra-parotid lymph nodes [37-42]. Non-AIDS Kaposi's sarcoma cases have been identified in the palate and oropharynx [38].

\subsection{Malignant peripheral nerve sheath tumor (1 case)}

Synonyms of malignant peripheral nerve sheath tumor are neurogenic sarcoma, malignant schwannoma, neurofibrosarcoma, Triton's tumor [7]. It is a spindle cell sarcoma usually arising in proximity to peripheral nerves or shows nerve sheath differentiation. In $80 \%$ of the cases occurrence is in adults and in $20 \%$ in children and adolescents [43]. The clinical presentation is that of an enlarging soft-tissue mass arising in the head and neck region with or without pain and dysesthesia [7].

\subsection{Chondrosarcoma (1 case)}

It is a rare malignant tumor of the head and neck region [37-38]. Most of the remaining chondrosarcomas of the head and neck region occur in the mandible and the larynx [39-42]. Patients generally present in the third and fourth decades of life, with symptoms dependent on the affected site [39].

The usual presentation of a sarcoma in the head and neck is a painless mass that, depending on the site of origin, represents an enlarging subcutaneous or submusosal mass. A high index of suspicion is necessary, dispite the relative rarity of these lesions, because prompt diagnosis and appropriate management affect outcome. Histologic grade is a reliable predictor of prognosis and is a designated component of the American Joint Committee on Cancer staging system for sarcomas [4]. Cancers as angiosarcoma, synovial sarcoma, osteosarcoma are considered as high-grade lesions [13, 44-45], dermatofibrosarcoma protuberans as low-grade neoplasm [46-47]. Other types of sarcomas, including fibrosarcoma, leiomyosarcoma, liposarcoma, chondrosarcoma, require individualized grading according to pathologic analysis [4]. Genetic and environmental factor contribute to the development of sarcomas. The genetic factors include p53, Rb1 while environmental include radiotherapy $[4,48]$.

\section{Results}

The man/woman ratio was $2: 1$. As far as age concerned, the most affected age range was between 60 and 80 years. The mean age of the patients was 62 (Figure 1)

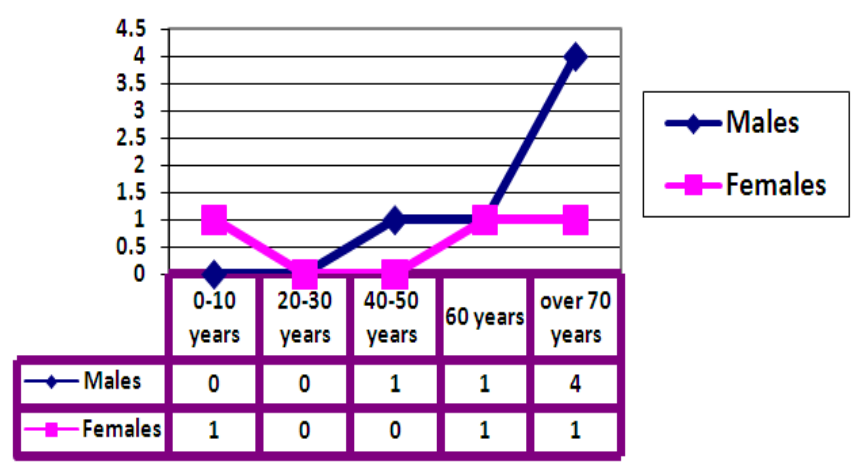

Figure1. Demographics.

As far as pathology is concerned, we found 7 histopathological variations of sarcomas (leiomyosarcoma, rhabdomiosarcoma, fibrosarcoma, ephithelioid sarcoma,

Kaposi sarcoma, malignant peripheral nerve sheath tumor, chondrosarcoma), and the most common type was the leiomyosarcoma (Figure 2).

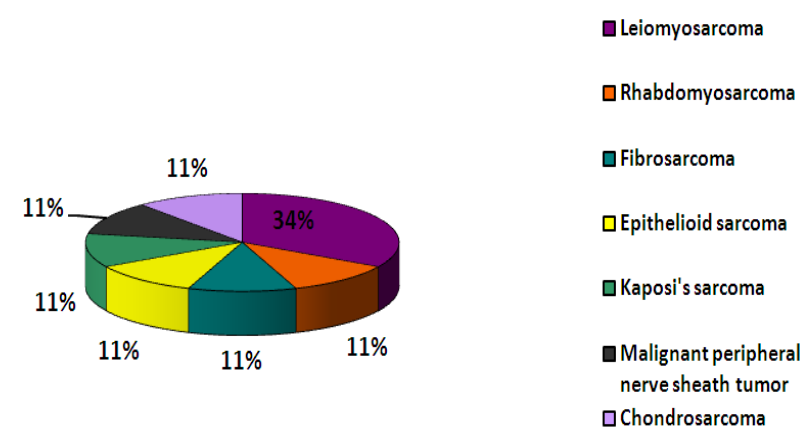

Figure 2. Percentage of the histological subtypes of sarcoma. 
Site of tumor origin was grouped into the following anatomical locations: 1 Nasopharynx, mastoid and temporal region, 1 Thyroid gland, 1 Parapharyngeal region, 3 Parotid gland (2 primary and 1 metastatic), 1 Larynx, 1 Nasal cavity, 1 Base of the tongue and free edge of the epiglottis. Fine-needle aspiration (FNA) was the first step to obtain a histologic diagnosis of a mass. When the sample was insuf

ficient, we performed a biopsy. CT and /or MRI are used to evaluate the extent of the primary lesion the regional lymphnodes and distant metastases. Disease was staged according to the American Joint Committee on Cancer (AJCC). It is based on grade, tumor size, lymphnode involvement and distant metastases (Table III) [49].

Table 3. Definition of TNM

\begin{tabular}{cc}
\hline TNM & Definition \\
\hline Primary tumor (T) & Primary tumor cannot be assessed \\
T0 & No evidence of primary tumor \\
T1 & Tumor $\leq 5$ cm in greatest \\
T1a & dimension \\
T1b & Superficial tumor \\
T2 & Deep tumor \\
T2a & Tumor $>5$ cm in greatest \\
T2b & dimension \\
RX & Superficial tumor \\
Regional lymph nodes (N) & Deep tumor \\
N0 & Regional lymph nodes cannot be \\
N1 & assessed \\
MX & No regional lymph nodes \\
M0 & metastasis \\
M1 & Regional lymph nodes metastasis \\
Distant metastasis (M) & Distant metastasis cannot be \\
\end{tabular}

Multimodality therapy is the most common strategy for patients with sarcomas of head and neck region. The methods of treatment we used were 2 :surgical treatment and chemotherapy. Although we must remember that the head and neck poses particular surgical problems however because of the proximity of so many important structures and the near impossibility of obtaining wide surgical margins in many cases. The local recurrence rates for high-grade soft tissue sarcomas after surgical excision have been reported to be high as in the literature [5, 50-51]. 33\% of patients developed local recurrence in our study. For patients with local or regional recurrence, curative re-resection remains an option. Patients with one or a combination of negative factors (massive recurrence, extensive high-grade lesions, poor functional status, known distant disease) may be best served by palliative therapy or supportive care [51].

\section{Discussion}

Sarcomas represent a group of very rare diseases.
Literature shows survey studies involving head and neck sarcoma [5, 8-12, 52-64] which investigate patient profile and disease prognosis. In this study, in 20 years, the frequency of malignant head and neck neoplasms is about 1 every 2 years. The case number 1 concerns a child of only 6 years of which has been diagnosed with embryonal rhabdomyosarcoma parameningeal. The lesion involved the nasopharynx and left mastoid and temporal region. The chemotherapy treatment was chosen based on the extension of the tumor and the young age of the patient. After a disease-free interval, which lasted 4 years, the disease has recurred several times leading to death of the patient 15 years after the first response. This case report reflects many of the features of sarcoma: it is not a frequent tumor and it has come back several times in spite of a continuous surveillance and several cycles of chemotherapy with various chemotherapeutic drugs. Our 3 cases of leiomyosarcoma, even though insurgents in different locations (thyroid gland, larynx and base of the tongue and free edge of the epiglottis), were all treated surgically and today 2 of them (case 5 and 9) are alive and disease free. The case number 3 is a Kaposi's sarcoma. Lesions similar to that found by us in the right parapharyngeal region had already been detected at the level of his lower limbs. Based on the histological nature we decided to submit it to $6,000,000$ $\mathrm{U} / 24 \mathrm{~h}$ alpha-interferon in cycles of 15 days with 3-4 weeks intervals for a 6 months period. After 3 months of treatment the patient achieved a good remission with improvement of symptoms. But after 5 months of therapy there was the death of the patient for acute myocardial infarction. The case number 4 concerns a patient treated surgically for epithelioid sarcoma arising from the left parotid gland. The surgical treatment led to complete removal of the left parotid gland and the functional latero-cervical left dissection (levels 2-4). Despite surgery, the tumor aggressiveness has led to the death of the patient in few months. Cases number 6 and 8 , a chondrosarcoma and myxofibrosarcoma, were treated surgically and patients are now alive disease free. The case number 7 concerns a very aggressive form of malignant peripheral nerve sheath tumor (MPNST) arose for the first time in 2007 in the skin of the left scalp. The lesion was treated surgically because it was several times relapsed. About 3 months ago, the patient came to our department for left metastatic parotid lesion. He was treated surgically but this was not sufficient to eradicate the disease. The patient has been sent to a sarcoma center for choose the ideal treatment where a chemo-radiotherapy has been proposed. The international literature agrees that is difficult to establish a standard treatment for head and neck sarcoma [54, 65]. The optimal treatment is complete resection [5, 65-66]. Postoperative adjuvant radiotherapy is indicated for patients with low-grade tumors who have close $(<1 \mathrm{~cm})$ or positive margins, as well as those with high-grade tumors [66-67]. Patients with incompletely resectable tumors are treated initially with radiotherapy $[50-51,66]$. The value of adjuvant chemotherapy is unclear $[48,66]$. Chemotherapy 
may be useful in local control of disease and in case of distant metastases [66, 68-72].

\section{Conclusion}

The data in this study show that head and neck sarcomas are rare tumors with high histological variability, which may involve different anatomical sites. The affected individuals were 9 , in the age range between 6 and 77, with mean age of 62. The predominant histological type was the leiomyosarcoma and the most common locations were the face and the neck. The most common treatment modes were surgery and chemotherapy. Sarcomas of the head and neck region represent a heterogeneous group of tumors with distinct prognostic implications. They are rare and not well-known lesions so we need further epidemiological studies, in order to provide us with more knowledge about the disease.

\section{References}

[1] Adisa AO, Adeyemi BF, Oluwasola AO, Kolude B, Akang EEU, Lawoyin JO, "Clinico pathological profile of head and neck malignancies at University College Hospital, Ibadan, Nigeria," Head \& Face Medicine, vol. 7, pp. 1-9, 2011.

[2] McMains CK, Gourin CG, "Pathology: Sarcomas of the head and neck," Emedicine, 2007.

[3] Wanebo HJ, Koness RJ, MacFarlane JK, "Head and neck sarcoma: report of the Head and Neck Sarcoma Registry. Society of Head and Neck Surgeons Committee on Research," Head and Neck, vol. 14, pp. 1-7, 1992.

[4] Potter BO, Sturgis EM, "Sarcomas of the head and neck," Surg Oncol Clin N Am, vol. 12, pp. 379-417, 2003.

[5] Mendenhall WM, Mendenhall CM, Werning JW,Riggs CE, Mendenhall NP, "Adult head and neck sof tissue sarcomas," Head \& Neck, vol. 27(10), pp. 916-922, 2005.

[6] Barnes L, Eveson J, Reichart P, "World Health Organization classification of tumours," Pathology and genetics of tumours of the head and neck Lyon: IARC Press, 2005.

[7] Rapidis AD, "Sarcomas of the head and neck in adult patients: current concepts and future perspectives," Expert Rev. Anticancer Ther, vol. 8(8), pp. 1271-1297, 2008.

[8] Sturgis EM, Potter BO, "Sarcomas of the head and neck region," Curr Opin Oncol, vol. 15(3), pp. 239-252, 2003.

[9] Singh RP, Grimer RJ, Bhujel N, Carter SR, Tillman RM, Abudu A, "Adult Head and Neck Soft Tissue Sarcomas:Treatment and Outcome," Hindawi Publishing Corporation Sarcoma, pp. 1-5, 2008.

[10] Huber GF, Matthews TW, Dort JC, "Soft-tissue sarcomas of the head and neck: a retrospective analysis of the Alberta experience 1974 to 1999," Laryngoscope, vol. 116( 5), pp. 780-785, 2006.

[11] Chen SA, Morris CG, Amdur RJ, Werning JW, VillaretDB, Mendenhall WM, "Adult head and neck soft tissue sarcomas," American Journal of Clinical Oncology, vol. 28(3), pp.
259-263, 2005.

[12] Eeles RA, Fisher C, A'Hern RP, "Head and neck sarcomas: prognostic factors and implications for treatment," British Journal of Cancer, vol. 68(1), pp. 201-207, 1993.

[13] Farhood AI, Hajdu SI, Shiu MH, Strong EW, "Soft tissue sarcomas of the head and neck in adults," The American Journal of Surgery, vol. 160(4), pp. 365-369, 1990.

[14] Huber GF, Matthews TW, Dort JC, "Soft-tissue sarcomas of the head and neck: a retrospective analysis of the Alberta experience 1974 to 1999," Laryngoscope, vol. 116(5), pp. 780-785, 2006.

[15] Schenberg ME, Slootweg PJ, Koole R, "Leiomyosarcomas of the oral cavity. Report of four cases and review of the literature," J Craniomaxillofac Surg, vol. 21(8), pp. 342-347, 1993.

[16] Barnes L, Kanbour A, "Malignant fibrous histiocytoma of the head and neck. A report of 12 cases," Arch Otolaryngol Head Neck Surg, vol. 114(10), pp. 1149-1156, 1988.

[17] Vilos GA, Rapidis AD, Lagogiannis GD, Apostolidis C, "Leiomyosarcomas of the oral tissues: clinicopathologic analysis of 50 cases," J Oral Maxillofac Surg, vol. 63(10), pp. 1461-1477, 2005.

[18] Estilo CL, Huryn JM, Kraus DH, "Effects of therapyvon dentofacial development in long-term survivors of head and neck rhabdomyosarcoma: the memorial sloan-kettering cancer center experience," J Pediatr Hematol Oncol, vol. 25(3), pp. 215-222, 2003.

[19] Callender TA, Weber RS, Janjan N, "Rhabdomyosarcoma of the nose and paranasal sinuses in adults and children," Otolaryngol Head Neck Surg, vol. 112, pp. 252-7, 1995.

[20] el-Naggar AK, Batsakis JG, Ordonez NG, "Rhabdomyosarcoma of the adult head and neck: a clinicopathological and DNA ploidy study," J Laryngol Otol, vol. 107, pp. 716-20, 1993.

[21] Nayar RC, Prudhomme F, Parise O Jr, "Rhabdomyosarcoma of the head and neck in adults: a study of 26 patients," Laryngoscope, vol. 103, pp. 1362-6, 1993.

[22] Hosoi H, Teramukai S, Matsumoto Y, "A review of 331 rhabdomyosarcoma cases in patients treated between 1991 and 2002 in japan," Int J Clin Oncol, vol. 12(2), pp. 137-145, 2007.

[23] La Quaglia MP, Heller G, Ghavimi F, The effect of age at diagnosis on out come in rhabdomyosarcoma, Cancer, vol. 73, pp. 109-17, 1994.

[24] Frankenthaler R, Ayala AG, Hartwich RW. Fibrosarcoma of the head and neck. Laryngoscope 1990: 100; 799-802.

[25] Mark RJ, Sercarz JA, Tran L, "Fibrosarcoma of the head and neck: the UCLA experience," Arch Otolaryngol Head Neck Surg, vol. 117, pp. 396-401, 1991.

[26] Greager JA, Reichard K, Campana JP, "Fibrosarcoma of the head and neck," Am J Surg, vol. 167, pp. 437-9, 1994.

[27] Jay A, Piper K, Farthing PM, Carter J, Diwakar A, "Low-grade myofibroblastic sarcoma of the tongue," Oral Surg. Oral Med. Oral Pathol. Oral Radiol. Endod, vol. 104(5), pp. e52-e58, 2007. 
[28] Jameson CF, Simpson MT, Towers JF, "Primary epithelioid sarcoma of the hard palate. A case report," Int J Oral Maxillofac Surg, vol. 19(4), pp. 240-242, 1990.

[29] Ramirez-Amador V, Martinez-Mata G, Gonzalez-Ramirez I, Anaya-Saavedra G, de Almeida OP, "Clinical, histological and immunohistochemical findings in oral Kaposi's sarcoma in a series of Mexican AIDS patients. Comparative study," J Oral Pathol Med, vol. 38(4), pp. 328-33, 2009.

[30] Feller L, Wood NH, Lemmer J, "HIV-associated Kaposi sarcoma: pathogenic mechanisms," Oral Surg Oral Med Oral Pathol Oral Radiol Endod, vol. 104(4), pp. 521-9, 2007.

[31] Schwartz RA, Micali G, Nasca MR, Scuderi L, "Kaposi sarcoma: a continuino conundrum," J Am Acad Dermatol, vol. 59(2), pp. 179-206, 2008.

[32] Szajerka T, Jablecki J, "Kaposi’s sarcoma revisited," AIDS Rev, vol. 9(4), pp. 230-6, 2007.

[33] Lanternier F, Lebbè C, Schartz N, Farhi D, Marcelin AG, Kèrob D, "Kaposi's sarcoma in HIV-negative men having sex with men," AIDS, vol. 22(10), pp. 1163-8, 2008.

[34] Sissolak G, Mayaud P, “AIDS-related Kaposi's sarcoma: epidemiological, diagnostic, treatment and control aspects in sub-Saharan Africa," Trop Med Int Health, vol. 10(10), pp. 981-92, 2005.

[35] Schwartz RA, "Kaposi’s sarcoma: an update," J Surg Oncol, vol. 87(3), pp. 146-51, 2004.

[36] Iscovich J, Boffetta P, Franceschi S, Azizi E, Sarid R, "Classic kaposi sarcoms: epidemiology and risk factors. Cancer 200AIDS registry linkage study. Classic Kaposi's sarcoma in Italy, 1985-1998," Br J Cancer, vol. 92(1), pp. 188-93, 2005.

[37] Mohanna S, Bravo F, Ferrufino JC, Sanchez J, Gotuzzo E, "Classic Kaposi's sarcoma presenting in the oral cavity of two HIV-negative Quechua patients," Med Oral Patol Oral Cir Bucal, vol. 12(5), pp. E365-368, 2007.

[38] Patrikidou A, Vahtsevanos K, Charalambidou M, Valeri RM, Xirou P, Antoniades K, "Kaposi's sarcoma in the head and neck area," Head Neck, vol. 31(2), pp. 260-8, 2009.

[39] Pagani D, Bellinvia M, Capaccio P, Scoppio Brambilla L, Pignataro L, "An unusual cause of a parotid mass in an immunocompetent host: classic Kaposi's sarcoma," Tumori, vol. 95(2), pp. 248-50, 2009.

[40] Cottoni F, Masala MV, Piras P, Montesu MA, Cerimele D, "Mucosal involvement in classic Kaposi's sarcoma," Br J Dermatol, vol. 148(6), pp. 1273-4, 2003.

[41] Reis-Filho JS, Souto-Moura C, Lopes JM, "Classic Kaposi's sarcoma of the tongue: case report with emphasis on the differential diagnosis," J Oral Maxillofac Surg, vol. 60(8), pp. 951-4, 2002.

[42] Puxeddu R, Parodo G, Locci F, Puxeddu I, Manconi PE, Ferreli C, "Parotid mass as an early sign of Kaposi's sarcoma associated with human herpesvirus 8 infection," J Laryngol Otol, vol. 116(6), pp. 470-3, 2002.

[43] Hajdu SI, "Peripheral nerve sheath tumors. Histogenesis, classification, and prognosis," Cancer, vol. 72(12), pp. 3549-3552, 1993.
[44] Wanebo HJ, Koness RJ, MacFarlane JK, "Head and neck sarcoma: report of the Head and Neck Sarcoma Registry. Society of Head and Neck Surgeons Committee on Research," Head Neck, vol. 14, pp. 1-7, 1992.

[45] Lawrence W Jr, "Operative management of soft tissue sarcomas: impact of anatomic site," Semin Surg Oncol, vol. 10, pp. 340-6, 1994.

[46] Weber RS, Benjamin RS, Peters LJ, "Soft tissue sarcomas of the head and neck in adolescents and adults," Am J Surg, vol. 152, pp. 386-92, 1986.

[47] Laskin WB, "Dermatofibrosarcoma protuberans," CA Cancer J Clin, vol. 42, pp. 116-25, 1992.

[48] Kraus DH, "Sarcomas of the Head and Neck," Current Oncology Reports, vol. 4, pp. 68-75, 2002.

[49] American Joint Committee on Cancer, "Soft tissue sarcoma," in Greene FL, Editor. AJCC cancer staging manual, 6thed, New York, Spanier SS, 2002, pp. 193-200.

[50] Parsons JT, Zlotecki RA, Reddy KA, Mitchell TP, Marcus Jr. RB, Scarborough MT, "The role of radiotherapy and limb-conserving surgery in the management of soft-tissue sarcomas in adults," Hematology/Oncology Clinics of North America, vol. 15(2), pp. 377-388, 2001.

[51] O'Sullivan B, Gullane P, Irish J, "Preoperative radiotherapy for adult head and neck soft tissue sarcoma: assessment of wound complication rates and cancer outcome in a prospective series," World Journal of Surgery, vol. 27( 7), pp. 875-883, 2003.

[52] Bree R, Valk PVD, Kuik DJ, Doornaert P, Buter J, "Prognostic factors in adult soft tissue sarcomas of the head and neck: a single-centre experience," Oral Oncol, vol. 42, pp. 703-9, 2006.

[53] Gorsky M, Epstein JB, "Head and neck and intra-oral soft tissue sarcomas,” Oral Oncol, vol. 34, pp. 292-6, 1998.

[54] Yamaguchi S, Nagasawa H, Suzuki T, Fujii E, Iwaki H, Takagi M, Amagasa T, "Sarcomas of the oral and maxillofacial region: a review of 32 cases in 25 years," Clin Oral Invest, vol. 8, pp. 52-5, 2004.

[55] Tran LM, Mark R, Meier R, Calcaterra TC, Parker RG, "Sarcomas of the head and neck. Prognostic factors and treatment strategies," Cancer, vol. 70, pp. 169-77, 1992.

[56] Nasri S, Mark RJ, Sercarz JA, Tran LM, Sadeghi S, "Pediatric sarcomas of the head and neck other than rhabdomyosarcoma," Am J Otolaryngol, vol. 3, pp. 165-71, 1995.

[57] Lajer CB, Daugaard S, Hansen HS, Kirkegaard J, Holmgaard S, Christensen ME, "Soft tissue sarcomas of the head and neck: a single-centre experience," Clin Otolaryngol, vol. 30, pp. 176-82, 2005.

[58] Penel N, Van Haverbeke C, Lartigau E, Vilain MO, Ton Van J, Mallet Y, "Head and neck soft tissue sarcoma of adult: prognostic value of surgery in multimodal therapeutic approach,” Oral Oncol, vol. 40, pp. 890-7, 2004.

[59] Gorsky M, Epstein JB, "Craniofacial osseous and chondromatous sarcomas in British Columbia - a review of 34 cases," Oral Oncol, vol. 36, pp. 27-31, 2000. 
[60] Le QT, Fu KK, Kroll S, Fitts L, Massullo V, Ferrell L, "Prognostic factors in adult soft tissue sarcoma of the head and neck," Int J Radiat Oncol Biol Phys, vol. 37, pp. 975-84, 1997.

[61] Dijkstra MD, Balm AJM, Coevorden FV, Gregor RT, Hart AA, Hilgers FJ, "Survival of adult patients with head and neck soft tissue sarcomas," Clin Otolaryngol, vol. 21, pp. 66-71, 1996.

[62] Dudhat SB, Mistry RC, Varughese T, Fakih AR, Chinoy RF, "Prognostic factors in head and neck soft tissue sarcomas," Cancer, vol. 89, pp. 868-72, 2000.

[63] Kraus DH, Dubner S, Harrison LB, "Prognostic factors for recurrence and survival in head and neck soft tissue sarcomas," Cancer, vol. 74, pp. 697-702, 1994.

[64] Bentz BG, Singh B, Woodruff J, Brennan M, Shah JP, Kraus $\mathrm{D}$, "Head and neck soft tissue sarcoma: a multivariate analysis of outcome," Ann Surg Oncol, vol. 11, pp. 619-28, 2005.

[65] Pacheco IA, Alves APNN, Mota MRL, de Almeida PC, Holanda ME, de Souza EF, Sousa FB, "Clinicopathological study of patients with head and neck sarcomas," Braz J Otorhinolaryngol, vol. 77(3), pp. 385-90, 2011.

[66] Wax MK, "Adult head and neck soft tissue sarcomas," Head \& Neck, pp. 916-22, 2005.

[67] Balm AJ, Vom Coevorden F, Bos KE, "Report of a symposium on diagnosis and treatment of adult soft tissue sarcomas in the head and neck," Eur J Surg Oncol, vol. 21, pp. $287-289,1995$

[68] Blay JY, van Glabbeke M, Verweij J, “Advanced soft-tissue sarcoma: a disease that is potentially curable for a subset of patients treated with chemotherapy," Eur J Cancer, vol. 39, pp. 64-69, 2003.

[69] van Oosterom AT, Mouridsen HT, Nielsen OS, "Results of randomized of the EORTC soft tissue and bone sarcoma group (STBSG) with two different ifosfamide regimens in first and second -line chemotherapy in advanced soft tissue sarcoma patients," Eur J Cancer, vol. 38, pp. 2397-2406, 2002.

[70] Frustaci S, Gherlinzoni F, De Paoli A, “Adjuvant chemotherapy for adult soft tissue sarcomas of the extremities and girdles: results of the Italian randomized cooperative trial," J Clin Oncol, vol. 19, pp. 1238-1247, 2001.

[71] Gortzak E, Azzarelli A, Buesa J, “A randomised phase II study on neo-adjuvant chemotherapy for 'high-risk' adult soft-tissue sarcoma," Eur J Cancer, vol. 37, pp. 1096-1103, 2001.

[72] Sarcoma meta-analysis collaboration, "Adjuvant chemotherapy for localised resectable soft-tissue sarcoma of adults: meta-analysis of individual data," Lancet, vol. 350, pp. 1647-1654, 1997. 